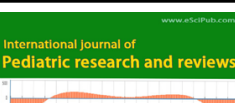

International Journal of Pediatric Research and Reviews

(ISSN:2637-4978)

(ISSN:2637-4978)

\title{
Importance of Psychoanalysis of Childhood Drawings for Prediagnosis of Mental Diseases
}

Matheus Alves Siqueira de Assunção', Francisco Henrique da Silva², Evandro Valentim da Silva ${ }^{3}$, Fálba Bernadete Ramos dos Anjos ${ }^{4}$

${ }^{1}$ Graduates of the Biological Sciences course - Bachelor's Degree, Biological Sciences Center, Federal University of Pernambuco (UFPE); ${ }^{2}$ Department of Biochemistry, Universidade Federal de Pernambuco, Recife, Pernambuco, Brazil; ${ }^{3}$ Clinical Hospital (UFPE); ${ }^{4}$ Professor Doctor of the Federal University of Pernambuco (UFPE).

\section{ABSTRACT}

Psychoanalysis and its application in the biological area.

The area of Psychology already presents a lot of research in the context, looking for artificial and laboratory situations; however, the importance of contextual analysis of the individual as a whole, of their daily activities and, from this, the understanding of their perceptions. Through psychoanalysis it is possible to observe widely the subject as a whole, not focusing on the presence of organic or genetic disorders, Ansermet (2003) addresses this problem by stating that "We cannot see the subject only as someone who manifests an organic or mental defect, according to the logic of disability". The systems that compose and organize the environment, according to Bronfenbrenner (1996), are constituted by the fitting of concentric structures called microsystem, what presents itself as the most active and direct contact environments, such as family, school or social work relationships; mesosystem referring to two or more environments of active social participation; exosystem, understood as environments that influence events that take place in the immediate environment of social relationship; and macrosystem, which comprise, in addition to the behavior of individuals, the connections between other people, the nature of bonds and the direct or indirect influence on the developing individual in the contexts in which they live and act actively.

The use of psychoanalysis as a tool to decipher possible mental disorders has become essential, since it is intrinsically linked to the biological look for the diagnosis of a patient. Autism, attention deficit disorder, depression and hyperactivity (ADHD), among other diseases that can be diagnosed during childhood or late they are psychosocial disorders that have their diagnoses complemented by psychoanalysis.

In this way, it is possible to perceive the challenges that psychoanalysis faces in terms of complementing the diagnosis of mental disorders in children, as well as the importance of psychosomatic studies in the elaboration of an accurate diagnosis that can be applied to children and their pathologists.
*Correspondence to Author:

Fálba Bernadete Ramos dos Anjos

Professor Doctor of the Federal

University of Pernambuco (UFPE).

How to cite this article:

Matheus Alves Siqueira de Assunção, Francisco Henrique da Silva, Evandro Valentim da Silva, Fálba Bernadete Ramos dos Anjos. Importance of Psychoanalysis of Childhood Drawings for Prediagnosis of Mental Diseases. International Journal of Pediatric Research and Reviews, 2020; 3:28.

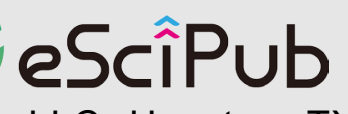

eSciPub LLC, Houston, TX USA. Website: https://escipub.com/ 
Psychoanalysis applied to children and their diseases.

In 1909, Freud published the first work on a child's psychological suffering, facing the difficulty of verbal language that restricted $\mathrm{him}^{33}$, since then, it was realized that psychoanalysis has an importance in clinical diagnosis, acting as an ally in the elucidation of childhood pathologies of a mental nature, these diseases being difficult to elucidate in children ${ }^{22}$.

Psychiatric diagnosis is a challenging task, both in adults and children, but in children it is more complex because its problem is expressed through maladaptive and deviant behaviors, rarely associated by the child with internal suffering ${ }^{9}$. The normality of child development is affected by living in stressful physical and mental health situations, these factors being determinants in psychosocial development within normality, however, in a situation of mental pathology, their behavior is modified. Your reaction to this unknown experience, which is the disease, can bring you feelings of guilt, fear, anguish, depression and apathy, and threaten your daily routine ${ }^{45}$.

In addition, other factors that must be taken into account are normalized behaviors up to a specific age range, where in others they are understood as pathological conditions of a mental nature, such as the difficulty of regulating impulsive, tolerance of frustration, difficulty of sustaining attention, fear and difficulties in speech $^{32}$.

According to child analyst Anna Freud, instead of putting yourself in a passive position before the transfer of the child, you should instead adopt an active stance. In this way, the importance of psychoanalysis is understood since, for the child, the analyst does not constitute an object of updating children's love schemes, but rather as a real person with whom the child can relate and share his affections. , serving, in this way, as an educational agent, assisting in the formation of his superego? ${ }^{2}$.
So that the behavior of the child is different when compared to the adult, it is necessary to have a differentiated and adapted view of mental illnesses in the different age groups, from their symptoms, diagnosis and treatments.

\section{Childhood depression}

Childhood depression is identified by the dominant medical-scientific discourse as a serious illness, especially because of the associated social disability. Childhood depression is identified by the dominant medical-scientific discourse as a serious illness, especially by the associated social disability. ${ }^{17,26}$, it appears as a disease, not just any state, being classified based on well-defined biometric parameters. It has been spreading rapidly in the population through the press, which does not always occur in an association restricted to the notion of disease. It is verified in general that this notion is simplified, allowing the term to be incorporated without distinction by the population, being a pathology explained mainly by genetic or organic and psychosocial factors, although the influence of external factors is not totally ruled out ${ }^{29}$.

\section{Childhood Autism}

Childhood autism is a personality disorder that manifests in early childhood through an abnormal development of language and relationships with others ${ }^{25}$. This disease is classified in the subgroup called "Invasive Development Disorder", showing deficiencies and invasive damage in multiple areas of development, including losses in reciprocal social interaction and communication, presenting stereotyped behaviors, interests and activities $^{11}$.

It is essential to have a dynamic view of the evolution of autistic symptoms, mainly due to the patient's age ${ }^{24}$, its diagnosis is based mainly on the patient's clinical condition, and there is still no biological marker that characterizes it ${ }^{11}$.

\section{Attention deficit and / or hyperactivity disorder (ADHD) in children}


Attention deficit and / or hyperactivity disorder (ADHD) is shown by some authors as a complex combination of genetic, biological, environmental and social factors. By highlighting genetic factors in ADHD, some studies indicate familiar phenotypic markers ${ }^{44}$, as well as genetic markers ${ }^{8,16,35}$ polygenetic transmission is also considered ${ }^{34,35,44,43}$.

Changes in the neural substrates that regulate executive functions have also been considered in the etiology of ADHD 41,5,15,6. The joint understanding of the biological and behavioral bases that contribute to the development and maintenance of the classic behaviors of this disorder seems to be fundamental for the implementation of more effective therapies.

According to the DSM-IV-RTM (involving the analysis of frequency, intensity, amplitude (persistence in another context) and duration (at least six months) of the symptomatic inattentionhyperactivity-impulsivity triad) and the ICD-10 ${ }^{31}$, with the aid of neurological exams ${ }^{7,34}$, three subtypes of the disorder were defined for ADHD, with a predominance of inattention, hyperactivity / impulsivity and a combination of the two previous ones.

Inattention in $A D H D$ derives from the malfunctioning of executive functions, characterized mainly by a difficulty in inhibiting behaviors and controlling interference, in addition to manifesting itself by frequent changes of subject, lack of attention in the speech of others, distraction during conversations, inattention or non-compliance with rules in recreational activities, constant alternation of tasks, in addition to reluctance to engage in complex tasks that require organization ${ }^{38,5}$.

Hyperactivity is characterized by excessive speech, day and night movement (during sleep), difficulty in sitting, while impulsivity involves acting without thinking, changing activities, difficulty in organizing work, need for supervision and difficulty in subject to wait his turn in playful activities or in group situations. These symptoms IJPRR:https://escipub.com/international-journal-of-pediatric-research-and-reviews/ impairments in the individual's development (functional criterion), be present in at least two (contextual criterion) and occur before the age of seven (temporal criterion, a non-excluding marker) ${ }^{38}$.

\section{Chronic diseases in children}

Chronic disease can be referred to as one that has a long course and can be incurable, leaving sequelae and imposing limitations on the individual's functions, requiring adaptation ${ }^{47}$. The main characteristic of chronic disease is the duration ${ }^{42}$. They define it as long-term, that is, a condition that lasts more than three months in a year or that requires a period of hospitalization for more than a month. In this study, we will adopt this definition.

In chronic cases, especially, children and adolescents have their daily lives modified, often with limitations, mainly physical, due to the signs and symptoms of the disease and can often be hospitalized for exams and treatment as the disease progresses. Thus, hospitalization permeates their growth and development processes, modifying, to a greater or lesser extent, their daily lives, separating them from the interaction with their families and the environment ${ }^{45}$.

\section{Analysis of drawings as a psychoanalytic tool.}

In the history of mankind it is verified that drawing is one of the most used forms of communication by man and preceded writing, thus indicating that communication through drawings is a form of basic and universal language ${ }^{46}$. The area of psychodiagnostic investigation is full of personality tests that use drawing as a means of communication and, in most cases, are accompanied by guidelines for the interpretation of the symbolic content associated with the different parts of the drawings (house, tree). , person or family), tending to a position where it is possible to decipher a design ${ }^{3}$, thus, one of the most important aspects for the integral development

\section{must be accompanied by significant}


of the individual is a mediating element of knowledge and self-knowledge ${ }^{19}$.

The Human Figure Drawing (DFH) as a psychological assessment technique has several interpretation systems, both evolutionary and emotional. For the evaluation of evolutionary aspects, those systems that include drawing as a measure of evaluation of children's cognitive development, such as Goodenough's, stand out ${ }^{3}$ Koppitz - Developmental Indicators ${ }^{23}$, the Naglieri ${ }^{28}$ and, on Brazil, the Wechsler ${ }^{46}$ and Sisto $^{39}$. From the drawing, the child organizes information, processes lived and thought experiences, reveals his learning and can develop a unique style of representation of the world ${ }^{19}$.

The child, on the other hand, does not intentionally send any coded message and the psychoanalyst does not have to show him allusively that he knows how to solve puzzles. It is in the course that the child discovers what he has to say and that is why he can enter the universe of discourse ${ }^{13}$. The production of images is a form of communication of affections that, from the one who produces it, stimulates those who observe them to come into contact with them, as a kind of language ${ }^{40}$.

According to Derdik (1989), the child, through drawing, interacts with the environment, experiences new realities and shares them with the world: drawing constitutes a total activity for the child, encompassing the set of its potentialities. When drawing, the child expresses the way in which he feels and exists ${ }^{5}$. As in the dream, drawing has two levels of expression: conscious and more or less intentional, which are the images represented in the drawing and the unconscious, where there are very complex symbols, that is, the unspoken content, content that goes beyond the images of the drawing, and that only with analysis of the therapist an interpretation will be possible ${ }^{27}$. Psychoanalysis was responsible for discovering the symbolic content presented in the drawing, where the content can represent a way of expressing the feelings of the subject who draws, being able to tell stories about him. Drawings can also express an affection, a joy or even anguish ${ }^{36}$.

As a measure of assessment of cognitive aspects, drawing is understood as an expression of developmental aspects, with a typical childhood cycle that can be observed from the graphic production. There is an intimate relationship between design and conceptual development. Children initially draw what they know, not what they see. With development, the child will try more and more to represent objects as he sees them, gradually appearing the concepts of size, proportion, relative position of the parts, spatial relationship and others. Although there are controversies about the design stages and, especially, about the linearity of their development process, most authors recognize typical stages in this process ${ }^{1}$.

Studying drawing as an element that defines the individual's perception of their environments should not be the exclusive concern of art educators, but of everyone concerned with the development of children's graphics, which can be easily interrupted as the child begins to live the school microsystem. Drawing is an important means of communication and representation of the child and presents itself as a fundamental activity, since from it the child expresses and reflects his ideas, feelings, perceptions and discoveries. For children, drawing is very important, it is their world, it is their way of transforming it, it is their most precious means of communication. In it are many of your fears, your wills, your needs and your achievements. Everything around them interacts, creating a very rich and extremely relevant representation system for the child ${ }^{19,18}$.

When drawing, the child projects a desire, perhaps in an attempt to obtain something he does not yet have ${ }^{12}$. Drawing for their own satisfaction, the children portray people, houses, trees, the grass, the sun. "Young children tend to ignore or transform reality in a subjective world, rich in fantasy. The drawings are representations and not reproductions". It is in 
the course that the child discovers what he has to say and that is why he can enter the universe of discourse ${ }^{14}$. In addition to all the meaning given to drawings, one must consider in front of a child, that he is in a process of development and construction of his personality structure, and that the use of drawing as language and expression also goes through a process of constitution $^{22}$.

In the representation of the child's drawing when carrying a mental disorder, one can perceive the increased care to be taken regarding the analysis of each case, seeking to understand the reason for each representation and, from there, take the shortcut to possible diagnosis. In autism, for example, even if there is no speech, the drawing is placed as a type of graphic production that allows communication with the therapist ${ }^{20}$.

Drawing is a way of expression, because when exercising such activity children symbolically represent their fantasies and how they position themselves in front of the world. The activity of drawing is a substitute for the free association (technique of psychoanalytic investigation) of the adult, as an aid for the child to express, through graphic productions, those moments, both those that were important and those that were distressing. In addition, it is essential that there is conversation with the child regarding its drawing, so that such production is presented with meanings even when the child does not say anything about it ${ }^{20}$. The development of a child's creative potential, whatever the type of activity in which he expresses himself, is essential to the innate growth cycle ${ }^{19}$.

Nilsson (2003) states that it is necessary to use some visual strategies, such as: individual daily programming, an individual work system, activities individually adapted for independent work, daily obligations presented visually, recreational activities and motor activities, giving additional support with guidance visual of the way the room is furnished and used 28,37 . This can be applied to all pathologies of a mental nature that can occur in childhood, be it autism, depression, ADHD, among others. In this context, the analysis is possible through a set of drawings, the identification of thematic axes for grouping and the analysis of the data drawn there, either focusing on the spelling used, as the meaning of the involvement of the oral language with the graphic production.

A drawing pattern is perceived in the spelling, be it the production of just one drawing, the use of a single color or the use of only one type of material even with other options offered, the behavior of the individual during the drawing process, many sometimes not allowing the act to be interrupted, showing irritation and frustration, or whether or not the child erases the drawing when he makes a mistake, when he draws over the error or around it, and when he makes a mistake he shows irritation or indifference. When giving voice to children, we realize the dimension that the disease has in their lives, which is experienced in a unique way, as a personal experience.

The child's emerging molar activities reflect the growing reach and complexity of the perceived ecological environment, both within and beyond the immediate environment, as well as the child's increasing ability to manage and change its environment according to its needs and desires. It is therefore essential to fill the children's imagination with everyday images filled with poetic meanings, enabling a more sensitive contact with the environments in which they live - natural or built - through the senses, such as touch and vision, starting from a selfknowledge for the child. knowledge of the other ${ }^{19}$.

Through theoretical knowledge linked to the interpretation of drawings, it is found that graphic production is an aid tool that contributes to the subjective constitution of the child. It is possible to perceive through this playful activity the reflection of the changes with regard to the shapes, borders and symbolic contents of the drawings, as well as their symbolism in the child's development. These processes occurred from the moment there is a bet on the subject 
and provide the child with the condition to enjoy some control over the other, differentiating himself from him.

It is possible to perceive that children with mental disorders have great possibilities as to constituting themselves as subjects, enrolling in the symbolic and becoming a desiring being, showing the ability to make use of the discourse, even though this is an idea that presents several controversies in the field of language study. Therefore, it is necessary to think about possible and future studies on this theme, whether in childhood autism, depression, ADHD or other pathologies, especially with regard to stereotypes and echolalia.

\section{Case subject to analysis}

A series of activities for children were applied in a non-governmental organization in the year 2018 from a project, seeking the production and diffusion of viable and innovative technologies for social inclusion. There is a multidisciplinary team of technicians and educators, as social capital, which does not materialize in professionalism and affects these issues related to the guarantee of the human rights of children and adolescents. The team consists of a pedagogue, social worker, psychologist, educators, as well as university students.

The project serves children, adolescents and their families through actions to combat child labor and domestic and sexual violence. Its activities include a reading workshop, information, capoeira, music (guitar, keyboard and singing / choir), as well as school monitoring and citizen participation. Linked to activities, there are also meetings with families, home visits and referrals to a social assistance support network, where each child was shown to live in environments of great need, among the applied activities, graphic representation was one of the tools to work with them (Annex 1). In this way, the drawings made by the children are liable for future psychoanalysis, taking into account the information highlighted in this chapter, reaffirming the importance and the different ways of applying it:

\section{References}

1. ABOU-JAMRA, C., \& CASTILLO, M. (1987). Teste de Matrizes Progressivas de Raven. In M. Ancona-Lopez (Ed.), Avaliação da inteligência: Vol. 2. São Paulo, SP: EPU.

2. ABRÃO, J.L.F. (2008). A introdução das ideias relativas à psicanálise de crianças no Brasil através da obra de Arthur Ramos.Memorandum, 14, 37-51. Retirado em 28/01/2020, da World Wide

Web

http://www.fafich.ufmg.br/ memorandum/a14/abr ao01.pdf

3. ALVES, I. (1981). O Teste Goodenough-Harris em pré-escolares paulistanos. Boletim de Psicologia, 80(33), 40-52.

4. ANSERMET, F. (2003). Clínica da origem:a criança entre a medicina e a psicanálise. (D. A. Seidl, trad.). Rio de Janeiro, RJ:Contracapa.

5. BARKLEY, R. A. (1997). Behavioral inhibition, sustained attention, and executive functions: Constructing a unifying theory of ADHD. Psychological Bulletin, 121, 65-94.

6. BARKLEY, R. A. (2002). Major life activity and health outcomes associated with AttentionDeficit/Hyperactivity Disorder. Journal of Clinical Psychiatry, 63, 10-15.

7. BARKLEY, R. A., ANASTOPOULOS, A. D., ROBIN, A. L., LOVETT, B. J., SMITH, B. H., CUNNINGHAM, C. E., SHAPIRO, C. J., CONNOR, D. F., DUPAUL, G. J., PRINCE, J. B., DOOLING-LITFIN, J. K., BIEDERMAN, J., MURPHY, K. R., RHOADS, L. H., CUNNINGH, L. J., PFIFFNER, L. J., GORDON, M., FARLEY, S. E., WILENS, T. E., SPENCER, T. J., HATHWAY, W. (2008). Transtorno de déficit de atenção/hiperatividade: manual para diagnostico e tratamento ( $3^{\circ}$ ed.). Porto Alegre: Artmed.

8. BIEDERMAN, J., \& FARAONE, S. (2005). Attention-deficit hyperactivity disorder. Lancet, 366, 237-248.

9. BIRD, H.R; DUARTE, C.S. 2002. Dados epidemiológicos em psiquiatria infantil. Revista Brasileira de Psiquiatria, 24:162-163. http://dx.doi.org/10.1590/S151644462002000400002

10. BRONFENBRENNER, U. (1996). A ecologia do desenvolvimento humano: Experimentos naturais e planejados. Porto Alegre: Artes Médicas. (Original publicado em 1979)

11. COSTA, MARIA IONE FERREIRA DA and NUNESMAIA, HENRIQUE GIL DA SILVA. Diagnóstico genético e clínico do autismo infantil. Arq. Neuro-Psiquiatr. [online]. 1998, vol.56, n.1, pp.24-31. ISSN 0004- 
282X. https://doi.org/10.1590/S0004282X1998000100004.

12. DI LEO, Joseph H. A interpretação do desenho infantil. Porto Alegre: Artes Médicas, 1987.

13. DIATKINE, R. (2007). As linguagens da criança e a psicanálise. Ide: Psicanálise e Cultura, 45, 3544.

14. DIATKINE, René. As linguagens da criança e a psicanálise. Ide, São Paulo, vol. 30, n. 45, p. 3544, dez. 2007. Disponível em: $<$ http://pepsic.bvsalud.org/pdf/ide/v30n45/v30n45 a07.pdf>. Acesso em: 17 nov. 2016.

15. FARAONE, S. V., BIEDREMAN, J. M. D., WEBER, W. B. A., \& RUSSELL, R. L. B. A. (1998). Psychiatric, Neuropsychological, and Psychosocial Features of DSM-IV Subtypes of AttentionDeficit/Hyperactivity Disorder: Results From a Clinically Referred Sample. Journal of the American Academy of Child \& Adolescent Psychiatry, 37(2), 185-193.

16. FARAONE, S. V., PERLIS, R. H., DOYLE, A. E., SOMLLER, J. W., GORALNICK, J., HOLMGREN, M. A., \& SKAR, P. (2005). Molecular Genetics of Attention-Deficit/Hyperactivity Disorder, Biological Psychiatry, 57(11), 1313 - 1323.

17. GILL SK, COFFEY BJ, PARK KS. Depressão na infância e na adolescência: manifestações clínicas, patogênese e tratamento. In: Lafer $B$, Almeida OP, Fraguas Jr R, Miguel EC, editores. Depressão no ciclo da vida. Porto Alegre: Artmed; 2000. p. 232-45.

18. GOLDBERG, L. G. (1999) Arte-Pré-Arte: um estudo acerca da retomada da expressão gráfica do adulto. Monografia de conclusão de curso Não-Publicada, curso de graduação em Educação Artística-licenciatura plena, Fundação Universidade Federal do Rio Grande.

19. GOLDBERG, LUCIANE GERMANO; YUNES, MARIA ANGELA MATTAR AND FREITAS, JOSÉ VICENTE DE. O desenho infantil na ótica da ecologia do desenvolvimento humano. Psicol. estud. [online]. 2005, vol.10, n.1, pp.97-106. ISSN 1413-7372. https://doi.org/10.1590/S141373722005000100012.

20. GONCALVES, RENATA CRISTINA. A influência do desenho na clínica psicanalítica para a constituição do sujeito: um estudo de caso sobre o autismo infantil. Estilos clin. [online]. 2017, vol.22, n.2, pp. 230-245. ISSN 1415-7128. http://dx.doi.org/10.11606/issn.19811624.v22i2p230-245.

21. GOODENOUGH, F. (1974). Test de inteligência infantil por medio del dibujo de la figura humana (7. ed.). Buenos Aires, Argentina: Paidós.
22. HERMES, ANDRÉIA INÊS, AND JERTO CARDOSO DA SILVA. "Simbologia do desenho na infância: um olhar psicanalítico." Boletim Entre SIS 2.1 (2017): 52-65.

23. KOPPITZ, E. M. (1984). El dibujo de la figura humana em los niños. Buenos Aires, Argentina: Guadalupe

24. LEBOYER M. Autismo infantil. Campinas: Papirus, 1987.

25. MCGILLIVRAY BC, HERBST DS, DILL FJ, SANDERCOCK HJ, TISCHLER B. Infatile autism: an occasional manifestation of fragile $X$ mental retardation. Am J Med Genet 1986; 23:325-358.

26. MENEZES PR, NASCIMENTO AF. Epidemiologia da depressão nas diversas fases da vida. In: Lafer B, Almeida OP, Fraguas Jr R, Miguel EC, editores. Depressão no ciclo da vida. Porto Alegre: Artmed; 2000. p. 29-36.

27. MĖREDIEU, Florence de. O desenho infantil. São Paulo: Editora Cultrix. 1974.

28. NAGLIERI, J. (1988). DAP: Draw a person: A quantitative scoring system. San Diego, CA: The Psychological Corporation.

29. NAKAMURA, EUNICE AND SANTOS, JOSÉ QUIRINO DOS. Depressão infantil: abordagem antropológica. Rev. Saúde Pública [online]. 2007, vol.41, n.1, pp.53-60. Epub Dec 04, 2006. ISSN 0034-8910. https://doi.org/10.1590/S003489102006005000011.

30. NILSSON, I. A educação de pessoas com desordens do espectro autístico e dificuldades semelhantes de aprendizagem.Temas sobre desenvolvimento, São Paulo, 2003, maio-junho, v. $12(68)$, p. 5-45.

31. ORGANIZAÇÃO MUNDIAL DE SAÚDE (1993). Classificação de transtornos mentais e de comportamentos da CID-10: descrições clínicas e diretrizes diagnósticas. Porto Alegre: Artmed

32. PAPOLOS, D.; PAPOLOS, J. 2007. The Bipolar Child: The Definitive and Reassuring Guide to Childhood's Most Misunderstood Disorder. New York, Three Rivers Press, $496 \mathrm{p}$.

33. RIVELLO, HARRISON. Psicanálise e infância: revisitando a obra de Françoise Dolto. Publicado em 10 de julho de 2012. Disponível em: $<$ http://www.webartigos.com/artigos/psicanalisee- infancia-revisitando-a-obra-de-francoisedolto/92265/\#ixzz4QIBOmryC>. Acesso em: 15 nov. 2016.

34. ROHDE, L. A., \& HALPERN, R. (2004). Transtorno de déficit de atenção/ hiperatividade: atualizado. Journal de Pediatria, 80(2), 61-70.

35. ROHDE, L. A., ZENI, C., POLANCZYK, G., \& HUTZ, M. (2004a). New insights on Attention- 
Deficit/Hyperactivity Disorder Pharmacogenimics.

Drug Development Research, 51, 1-8.

36. SALVADOR, Ana. Conhecer a criança através do desenho. Portugal: Porto Editora, 1988.

37. SANTOS, ANDRÉA RIZZO DOS, AND VERA LUCIA MESSIAS FIALHO CAPELLINI. "O professor da Educação Especial e o processo de ensino-aprendizagem de alunos com autismo." Revista Educação Especial (2013): 385-400.

38. SANTOS, LETÍCIA DE FARIA; VASCONCELOS LAÉRCIA ABREU." Transtorno do Déficit de Atenção e Hiperatividade em Crianças: Uma Revisão Interdisciplinar"Psicologia: Teoria e Pesquisa Out-Dez 2010, Vol. 26 n. 4, pp. 717-724

39. SISTO, F. (2006). O desenho da figura humana Escala Sisto. São Paulo, SP: Vetor.

40. SOUZA, AUDREY SETTON LOPES DE. "O desenho como instrumento diagnóstico: reflexões a partir da psicanálise." Boletim de Psicologia 61.135 (2011): 207-215.

41. SZOBOT, C. M., \& STONE, I. R. (2003). Transtorno de déficit de atenção/hiperatividade: bases neurológicas. Em L. A. Rohde, P. Mattos, e cols. (Orgs.) Princípios e práticas em Transtorno de Déficit de Atenção/Hiperatividade, (v. 3, pp. 53-62).
42. TETELBOM M, FALCETO OG, GAZAL $\mathrm{CH}$, SHANSIS F, WOLF AL. A criança com doença crônica e sua família: importância da avaliação psicossocial. J Pediatria 1993; 60 (1):5-11.

43. THAPAR, A., HOLMES, J., POULTON, K., \& HARREINGTON, R. (1999). Genetic basis of attention deficit and hyperactivity. The British Journal of Psychiatry, 174, 105-111.

44. TODD, R. D. (2000). Genetics of Attention Deficit Hyperactivity Disorder: are we ready for molecular genetic studies? American Journal of Medical Genetics (Neuropsychiatric genetics), 36, (3), 241-243.

45. VIEIRA MA, LIMA RAG. Crianças e adolescentes com doença crônica: convivendo com mudanças. Rev Latino-am Enfermagem 2002 julho-agosto; 10(4):552-60

46. WECHSLER, S. (2003). DFH III: O desenho da figura humana: Avaliação do desenvolvimento cognitivo de crianças brasileiras. Campinas, SP: Editora da Pontifícia Universidade Católica de São Paulo. (Original publicado em 1996)

47. WOODS NF, YATES BC, Primono J. Supporting families during chronic illness. Image: J Nurs Scholarship 1989; 21(1):46-50. 


\section{ANNEX 1}
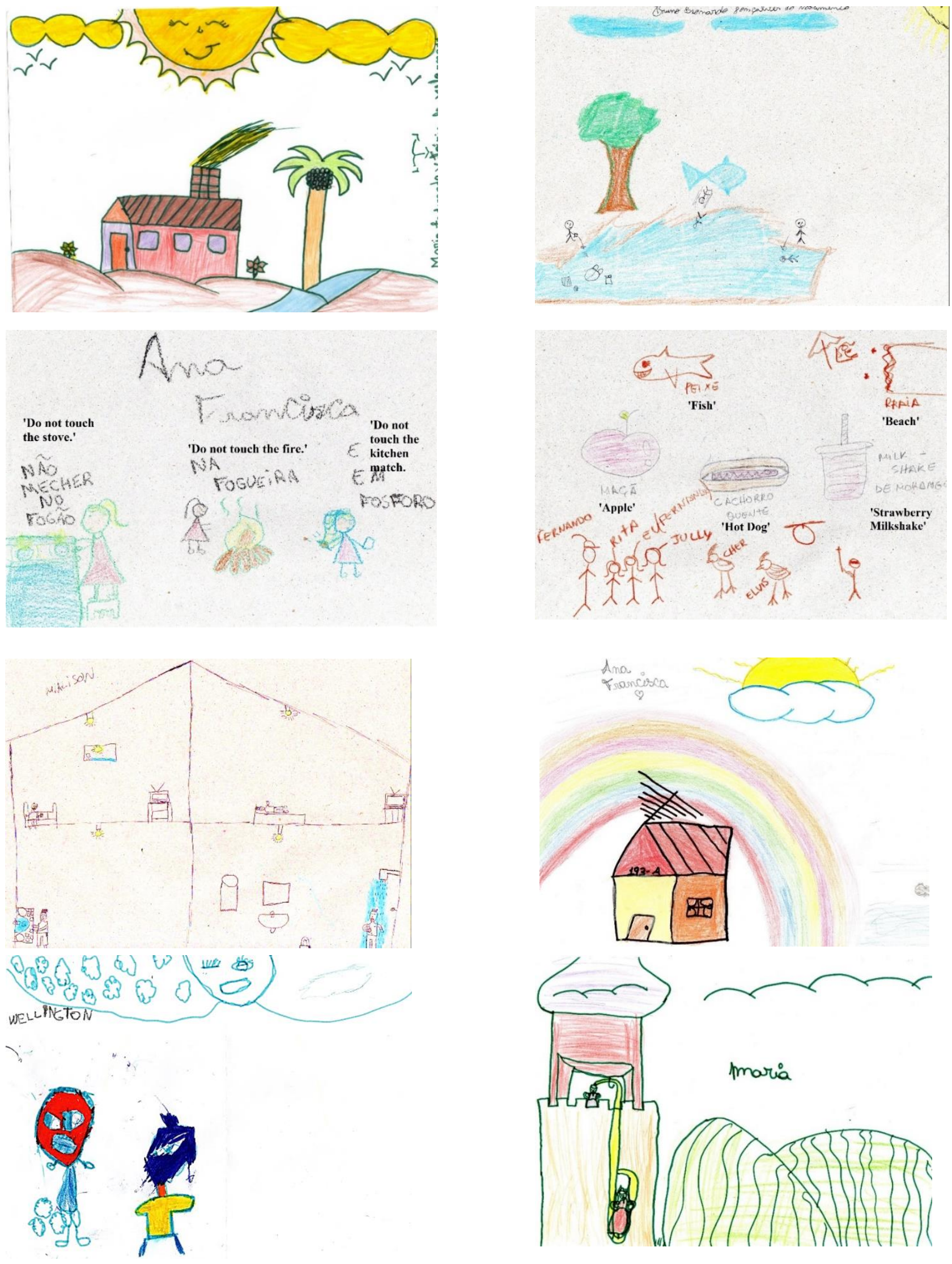
Matheus Alves Siqueira de Assunção et al., IJOPRR, 2020 3:28
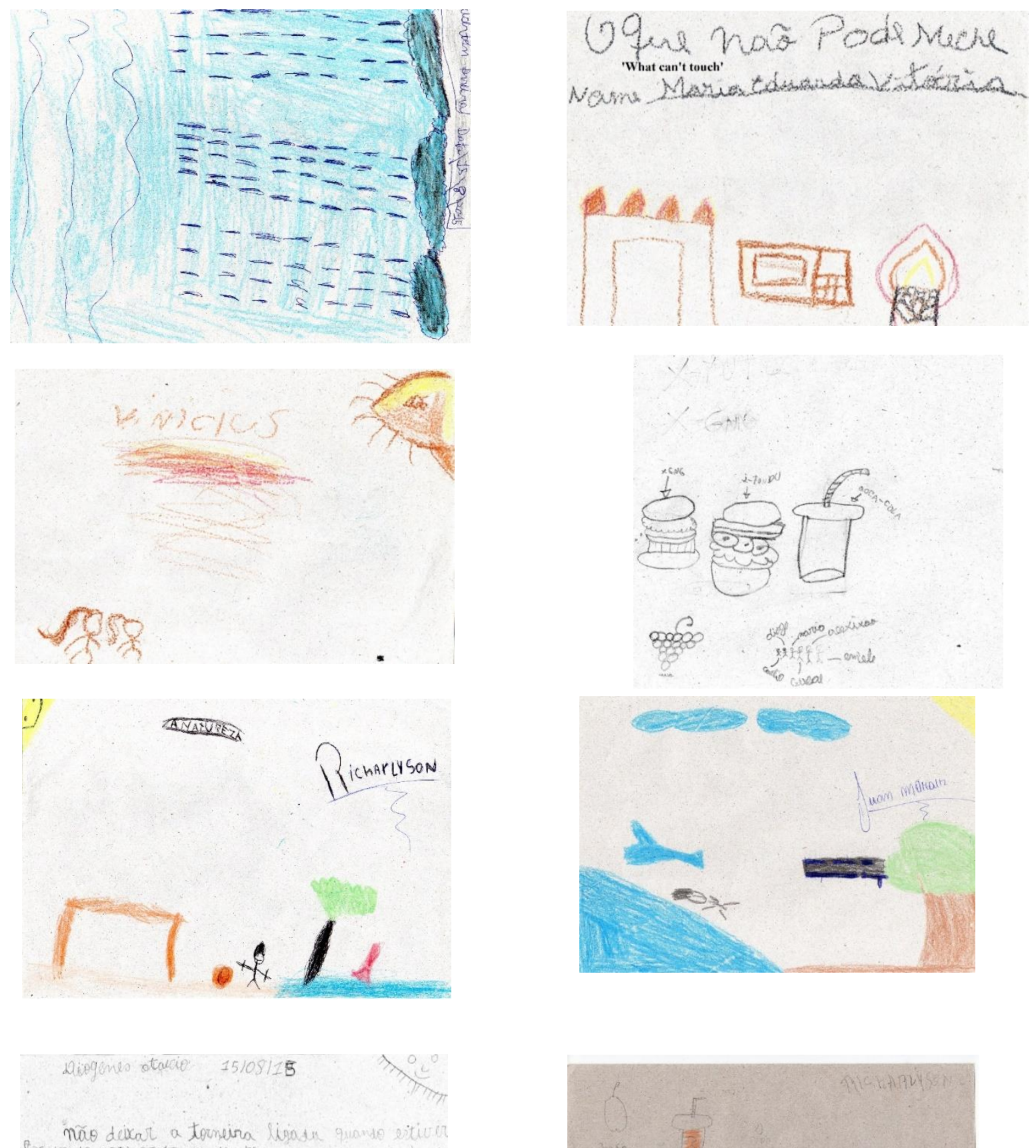

lxcovando os destes.

'Do not leave the tap 'on' when brushing your teeth.'

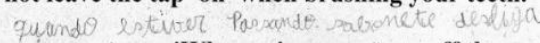

$\theta$ Chisivio. 'When using soap turn off the

shower'

Preseitar a chuvar para näo gostar agua.

'If you wash the bike, the bike, if it rains, take advantage of the rain so you don't waste water.'
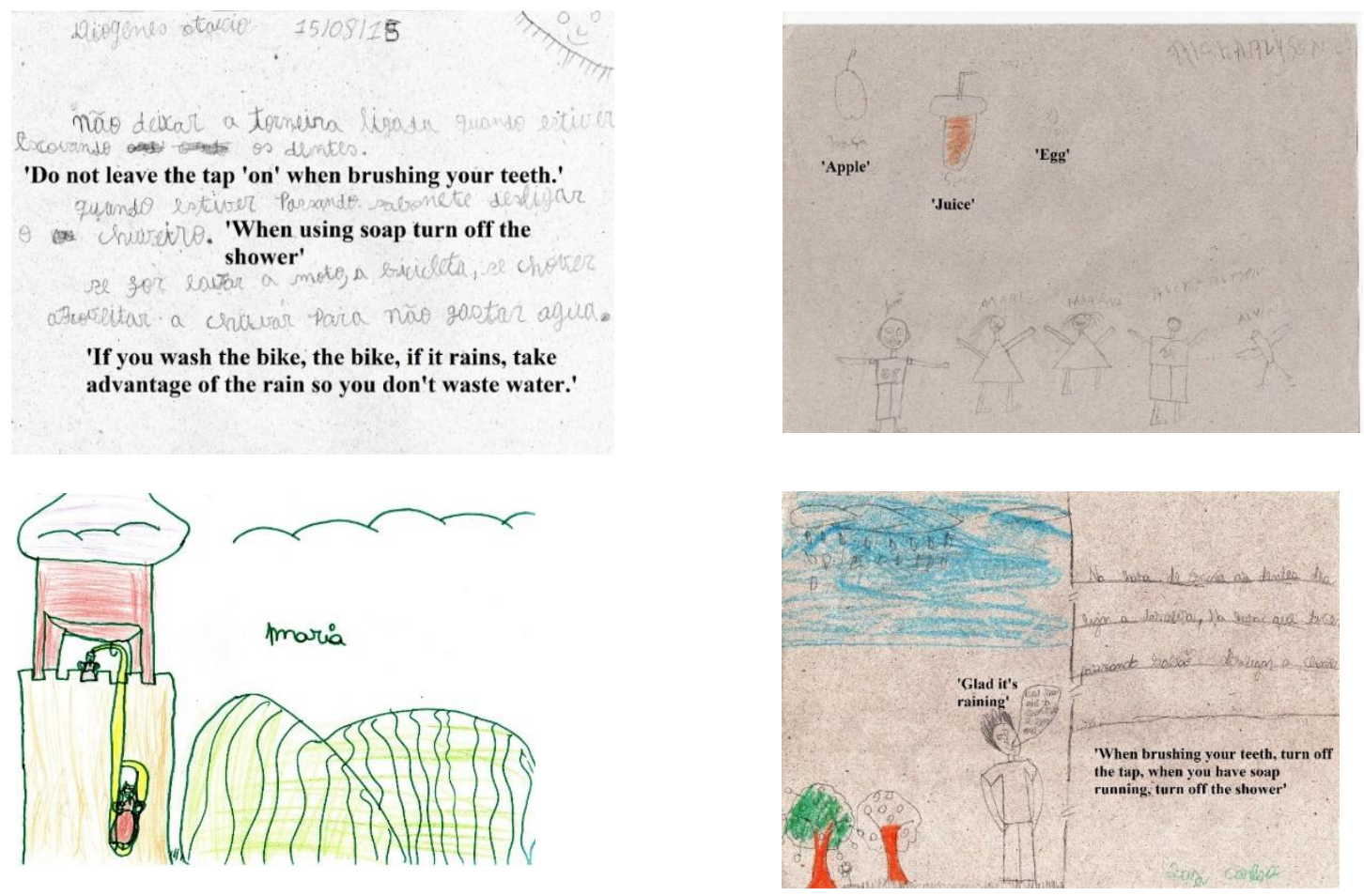

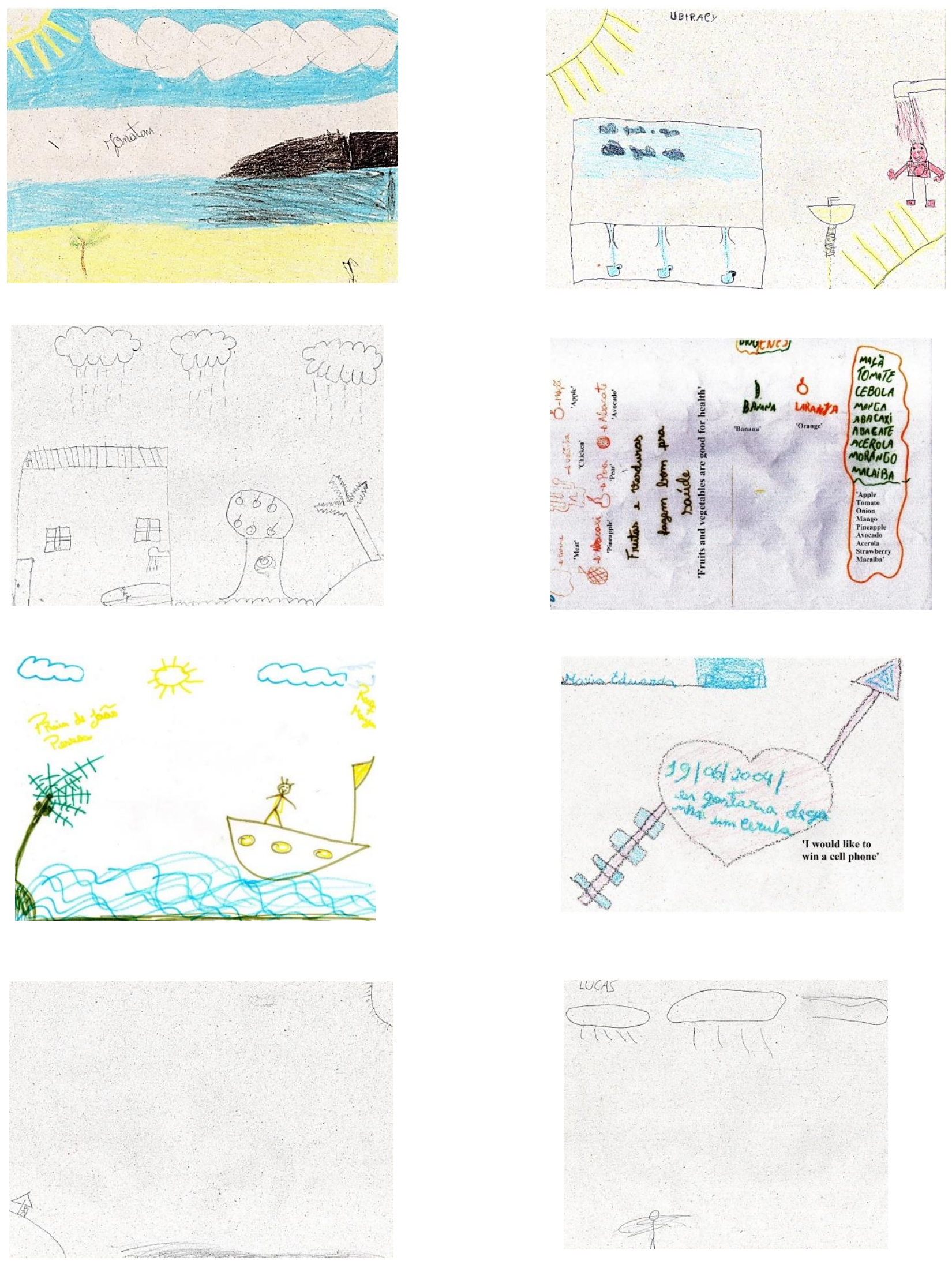